\title{
WONING ACTIVITIAS
}

FII iT DIVISION - Act1ve exploration with qualified fleld parties, conducted by the following compenies, has been suspended for the season: Coast Range Txploration Co., Anchorage, Alaska; W. s. Moore Co., Duluth, Minnesota; Northwest Venturea, Ltd., Vancouver, B. C.; and U. S. Steel Company. Activities of the above groups and others have regulted in the staking of many claims this past season with iron and copper appearing to be the metals of major intereat.

SECOND DIVISION - A second shipment of tin concentrates from the Lost River operetion of U. S. Tin Corp., amount $1 \mathrm{ng}$ to 138 tons valued at $\$ 150,000$, has been made to the Texas ctty Tin Sinelter.

Coplin Consolidated Enterprises, a gold dredging operation on the Nuikluk River at council, is anotber recent applicant for Territorial tax exemption as a "new operation" (Chapter 26, SIA 1953 - Mining Licenge Tax).

THIRD DIVISION - Kenal Chrome Company has finally made its first shipnent of ohrome ore to G.S.A. from the Red Mountain deposits near Seldovia. After finally obtalnIng shipplng space, over 3,000 tons of premiun grade ore were loaded in Jakalof Bay before a sudden storm forced the cargo vessel to pull away from the loading potnt for Seattle.

Northern Pyrites has completed a detalled electro-magnetio survey of the sulphide depoeit at Horseshoe Bay on Latouche Islend, Prince Wilifam Sound, and appear well satlafied with their regults.

FOURTH DTVISION - A costly fire at the Red Devil Mine of the DeCoursey Mountain Mining Company on 0otober 22 ceused danege estimated at $\$ 300,000$. Starting in the hoist house, the fire spread quickly to the power houge, blacksmith shop, mine bu:"dings and reduction plant. The bunkhouse, mine office and atorehouge were saved. The company plans to continue underground exploration, but it is estimated that production from the mine will be delayed about a year.

\section{RADIOACT IVITIES}

The TDM wag called upon to look tnto a recently reported urantum strike at Shirley Lake, 110 miles northwegt of Anchorage, Remembering the sad experience of the "Tishwhel" gold strike on the Yukon in 1949, and a portion of the Territorial lew esteblishing the TIM, which says it will "protect the interest of the 1nvestor," an examination was made of the area in question. A word of caution was extended, through the local press to those people improperly oquipped and not aware of the very unique properties of radioactivities and the special knowledge required to effectively evaluate findings, to "tread with caution."

The general area investigated does glve a radioactive count above "normal" or "background," but comercial grade material had not been found nor had any 
mi rals causing the radioetivity been identffied. Since the Shirlay Lake investigation, several other "discoveries" in Alaske have been reported by the press, but the TDM wishes to remind the general public that uranlum exploration and mining is a very apecialized fileld. Once a true uranium-bearine mineral has been locatod and identifled, it requires someone with plenty of capital and know-how to develop a prospect to the polnt where comercial grade material has been "blocked out" and returns may be realized by the locator.

\section{OIL NBWS}

Alagka 011 and Gas Development Compeny has suspended drilling operations for the 1954 season. A structurel faliure on the derrick, which will require minor repairs but whlch came at a time when 15 -degres temperatures were affecting the water supply, caused the company to ahut down for the year.

The recent earthquake, whose epleenter was in the vicinity of Homer, caused considerable danage in the Havenstrite operation at Iniskin Bay. The present hole was at a depth of 5,100 feet when the quake refllled 600 feet of it. Then, $a$ casing failure caused a "hang-up" of the dr1ll stem when the bit was 900 feet from the surface on 1 ts way out of the hole. At last leports the crew was attengting to cleer the bit and replece the casing section. Winter operation in this area is not feasible and drilling w111 cease when freezing temperatures cut of the water supply.

Excesa1ve rains have slowed down delivery of dlesel ofl by alr to the Icy Bay operationg of Phillips Potroleum Company. Continuous driling on the Sullivan No. I well is planned throughout the winter.

Rights of native Indians to potential oll lands in Alagkg will be discussed at public hearing scheduled for Anchorage, November 20. Leases and leese applioations covering over 130,000 sores in the Yakatet-Ioy Bay area, applied for by two different groups, are lnvolved in the hearing eet by Lowell Puckett, Area Administrator, Bureau of Land Management.

The offlce of Navel Petroleum Reserves, Department of the Nary, has made avaliable for public ingpection and study all well records and geological data relating to ofl exploration in Neval Petroloum Regerve No, 4, located in the vagt sedimentary besin lying north of the Brooks Range in Northern Alaske. The data may be consulted in the offices of the U. S. Geologioal Survey, Weshington, D. C., Room 2643, Interior Building, and in the office of the Inspector, Naval Petroleum Reserve No. 4, Falrbanks, Alagka.

\section{U. S. GEOLOGICAL SURVEY INFORMATION}

A preliminary geological reconnaissance uns of a portion of the Lower Kuskokwim area, Alaska, which may provide information helpfil in exploration for gold, pletinum and other minerals, has beon made avallable for public inspection.

An Index of mineral resources information on Alagka, in card form, has also been released. The above information may be conguited in the following Alaskan offlces; $210 \mathrm{E}$. F. Glover Buliding, Anchorage; Brooks Menorlal Mines Building, College; 117 Federal Building, Juneav; and the Territorial Department of Mines office, Juneau. 


\section{U. S. BURZAUI OR MINES RRORGANIZATION}

A general U. S. Bureau of Mineg reorganization, recently recommended by a aurvey team, will become effective Jenuary 1, 1955. Alaska, formerly Region I, will now cone under a new Reglon 1 1ncluding Veshington, Oregon, Idaho and inontena with headquarters at Albany, Oreson. No chenge of personnel at Juneau $1 \mathrm{~s}$ anticlpeted other than a elight reduotion $1 \mathrm{n}$ force which might result froin the usual number of resignations or tranafera.

\section{QUESTION}

How about an annual Alagkan prospectora' convention backed by the largo mining companies and supply houses interegted in Alaske?

\section{MEETAL PRICIS}

The following metal prices are taken from the weokly F. and M. J. Metel Markets reports of dates as indicated to show ourrent prices as well as trenda:

\begin{tabular}{|c|c|c|c|}
\hline & oct, 28, & Month & Year \\
\hline & $\frac{1954}{207 \pi}$ & $\frac{\mathrm{ABO}}{20 \mathrm{TA}}$ & $\frac{\text { Ago }}{29.6 \alpha}$ \\
\hline $\begin{array}{l}\text { Copper, per lb. } \\
\text { Lead, per lb. }\end{array}$ & $\begin{array}{l}29.7 \not \\
15 \not\end{array}$ & $\begin{array}{l}29.7 \not z \\
14-3 / 4 d\end{array}$ & $\begin{array}{l}29.6 \phi \\
13-1 / 2 \phi\end{array}$ \\
\hline Zinc, per $1 \mathrm{~b}$. & $11=1 / 2 q$ & $11-1 / 2 \phi$ & $10 q$ \\
\hline T1n, per 1b. & $92-1 / 3 \phi$ & $93-5 / 8 q^{\prime}$ & $81 d$ \\
\hline Quickstlver, per flask & $\$ 325-330$ & $4325-328$ & $\$ 104185$ \\
\hline Silver, per oz. & $85-1 / 4 \not$ & $85-1 / 4 \phi$ & $86-1 / 4 \phi$ \\
\hline Platinum, per oz. & $\$ 79-84$ & 出84-87 & $\$ 92-93$ \\
\hline Niokel, per $1 b$. & $60 \phi$ & $60 \%$ & $60 \phi^{\prime}$ \\
\hline Molytdomim, per 1b. & $\$ 3$ & $43^{\prime \prime}$ & $\$ 3$ \\
\hline Tungsten ore, per unit & 63 & $\$ 63$ & 63 \\
\hline
\end{tabular}

\section{AMERICAN MINING CONGRESS NEUS}

Part of the Deoleration of Polley adopted at the September meeting of the A.M.C. had to do with taxetion. Following were some of the chanfes reoommended to reatore normel incentives for eoonomle growth and developnent:

"Many of our tax rates are st1li too bigh to leave incentive for meximum ponomio effort and inltiative.

The orer-all tax rate on income of the individual or of the corporation ahould in no case exceed $50 \%$.

While a start has been made in an allowance to stockholders on dividends w1th respect to taxes paid by the corporation, the principle should be further extended, and depletion allowed to a mining corporetion should be carried through to the stockholder on some equitable bagla.

Substantial improvement hes been made in depreciation provisions and in thelr edministration, but there is still need that the tex benefit rule should be fully applied.

The linftations on deduotibility of exploration expenses bave been somewhat eased, but such limitations should be completely ellainated.

Tax exemption ahould be granted a new mine for three years after beginning of profitable operation.

Cep1tal gains should be taxed at more moderate ratea." 


\title{
COAL MINZRES EXAMLNING BOARD
}

The next meeting of the Territorial Coal Miners Examining Board, tontatively set for December 3 and 4, 1954, has been postponed unt11 December 10 and 11 . The meting will be held at the TDM offlce, 329 second Avenue, Anohorage, for the purpose of examining applicants for qualification as foremen and fire bossea in the coal mines of the Territory.

\section{URANIUM}

This is the most talked about element in the Territory today. Although uranium is one of the "newer" elements, several helpful pamphlets bave been pubIished which are useful to the prospector in his search for this very 1mportant source of energy. Prospecting with a counter, July, 1954, for 30 cents and Erospecting for Urantum, Oetober, 1951, for 45 centa are available from the Superintendent of Documents, $U$. S. Government Printing Office, raghington $25, D$. $C$. Prospecting for Uranlum in Canada, 1953, is avaliable for 50 cents from The Prospectors and Devielopers Assoolation, 67 Yonge Street, Toronto, Canada.

In the search for radioatives, one of two types of counters is generally used; 1.e.e.either the Gelger or scintillation counter. The heart of the Geiger oounter is the Gelger tube which is a metal-walled tube filled with one or more gas. 3, such as helium, argon, or kxypton. A positive charge of about 1,000 volts is ipplied between the metal wall of the tube and a center wire which acts as the other pole.

Radioactive elements emit alpha, beta and/or gamma rays. Both types of counters measure, in a relative aense, the emission of ganma rays from a sample or material "in place." The Geiger tube is discharged, or affected by, only about one percent of the garme rays which penetrate it, while the scintillation countar which uses a different type of "detector" will reapt to 50 percent or more of the Eama rays.

The "detector" in acintillation oounter is a sodium iodide or potassium lodide crystal whlch produces tiny momentary flecks of light (scintillatione) when penetrated by gamma rays. It can be seen, therefore, that the scintiliation counter $1 \mathrm{~s} 50$ or more times as sensitive as the Geiger counter.

One of the most important things to remenber in the use of all counters is the penetrating power of gamme rays. The gamma rays from uranium are stopped by approximately:

\author{
3 Inches of lead \\ 1 foot of rock \\ 2-1/2 feot of water \\ 15. feet of gnow \\ Several hundred feet of air
}

In other words, a counter measures only the gamna rays from the outer foot of a rock outcrop. It cennot detect radioactive ores deep within the rock.

A counter reading may be strongly influenced by the site of a sample tested. A large plece of radioactive rock gives of more gamma rays than a small pioce. Thr rafest way to check for "relative" radioactivity of samples is to erind them to \& pulp and then welgh out 8 uniform amount of each. These pulps placed in small envelopes of uniform thlcknesa and held at the same distance from the Geiger tube 
or sointillation counter will give a "relative" or "equlvalent" uraniun content. The TDM has a set of "standards," samples of known urantur content, at all fleld offices agalnst which you can oheck your counters.

In addition to urantum, several other elements are also radioactive. The only one sufficiently abundant to pose a problem in the field is thoriun, which has about two-fiftbs the ganma ray activity of uraniun. The most roliable way to determine the urenium content of a sample is to obtain a chemlcal analysis. This analysis determines uranlum drectly, and is not affected by decay products or thoriun which influence the Gelger counter.

Even after uranium is found and posttively ldentifted, the exploration and development of a promiaing area requires considerable cepltal and experience. Most areas require careful drilling and sampline. Then comes the problet of ore beneficlation, which is also a speclalized field. As far as Alask is concerned, no difficulty would be encountered in interesting one of the many qualifled uranium operators in the United States in a promising uranium deposit anywere in the Territory.

The TDM also wishes to polnt out that both the Atonlc Fnergy Comnission and the Territory of Alaska have established a $\$ 10,000$ bonus to any person who discovers and produces (and here is the catch) "the first twenty (20) short tons of uranium-bearing ores or mechanloal concentrates assaying 20 percent or more $\mathrm{U}_{3} \mathrm{O}_{8}$ by weight from any single mining location whlch bas not previously been worked for uranium." To our knowledge, nobody has collected this bonus to dete.

Marketing date on uranlum ores may be covered brlefly as follows: Ores are not scceptable to the Atomic Energy Commission, who is the sole purchaser,

(1) If the $\mathrm{U}_{3} \mathrm{O}_{3}$ content $1 \mathrm{~s}$ legs than 0.10 percent; (2) if they carry in excess of 6 percent 11me; (3) If they contein lumps in excese of 12 inches in size.

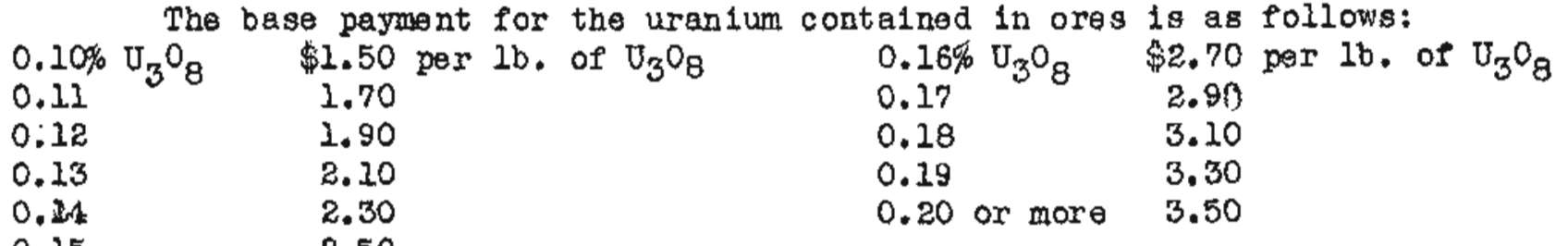

In addition to the above, there are two premiums:

(1) For each pound of $\mathrm{U}_{3} \mathrm{O}_{8} 1 \mathrm{il}$ excess of $42 \mathrm{ba}$. $-75 \%$ per $3 \mathrm{~b}$.

(2) For each pound of $\mathrm{U}_{3}^{\circ}$ in excess of $10 \mathrm{lbs}$. $25 \mathrm{~d}$ per $1 \mathrm{~b}$.

Fayment is also made for the ranadium content of these ores at the rate of 31 oents per pound of $\mathrm{V}_{2} \mathrm{O}_{5}$. Other allowances made by the Atomlo Energy Commission are 50 cents per pound of $\mathrm{U}_{3} \mathrm{O}_{8}$ for development purposes and six cents per wet ton mile (up to a maximum of 100 miles) for haulage allowance.

For full details of the purchase sohedules, the United States Atonic Energy Conmiasion should be consulted at $P, O$. Box 270, Grand Junction, Colorado. 